\title{
Analysis on the Innovative Ways of Teaching Method for Ideological and Political Course in Colleges of the New Media Era
}

\author{
Demin Li \\ Department of Social Science \\ Huanghe Science and Technology College \\ Zhengzhou, China
}

\begin{abstract}
This paper analyzes the negative influence of new media on the ideological and political education in colleges and proposes the innovative ways to reform the contents of ideological and political education, standardize practical teaching, enrich teaching forms and exert the function of campus network.
\end{abstract}

Keywords-new media; colleges; ideological and political course; teaching method; innovation; ways

\section{INTRODUCTION}

The ideological and political theory course teaches students about the systematic Marxist theory and serves as the main channel to achieve the ideological and political education for college students. In order to reach the expected results, we must pay attention to teaching method and means. If the method is proper, we can get twofold results with half the effort. Otherwise, we will get half the result with twice the effort even beat the air. The realistic background faced by ideological and political teaching in the new media era is unprecedented. It has positive and negative factors, opportunities and challenges.

\section{The Reasons That New Media Causes Negative} INFLUENCE ON IDEOLOGICAL AND POLITICAL EDUCATION ARE SHOWN AS FOLLOWS:

\section{A. The Ideological and Political Education Achieved through Single and Closed Thinking Is Ineffective.}

In the environment of traditional ideological and political education, the educators always have single and closed logical thinking. When the society is not open enough, although this thinking has drawbacks, undeniably, it plays an important role in training young people at that time. In the new media era, the extensive application of new media technology creates a new world-network world for people. It has been changing people's way of thinking. Under the social background, some educators of ideological and political education still stick to the traditional thinking, analyzing and solving problems in ideological understanding via the traditional thinking. Although making great efforts, they get the opposite of what

Project source: Philosophy and Social Science Planning Project of Henan Province, Project number: 2016G024. they want. It becomes the obstacle for ideological and political education to become effective.

\section{B. The Discourse of Ideological and Political Education Loses Effectiveness Because of the Severe Lag of Discourse Spread}

At present, the discourse of ideological and politica education has obstacles because the spread means of discourse is seriously backward. It fails to fully embody the regulatory function, leading to negative factors. The reasons are as follows: firstly, in the new media era, the information spreads fast to a wide range. The contents and discourse of ideological and political education fail to keep up with the social development. The educator cannot use discourse of ideological and political education to effectively communicate with the educatee. Secondly, in the new media era, because the transmission of information is two-way and the sender of information can also become receiver, it greatly improves the passive position of audiences when the traditional media spreads knowledge. Educatee gets information at the same time with educators even earlier than them. The spread of discourse of ideological and political education is asymmetric. Thirdly, in the new media era, subjects are equal and have equal speaking right in the virtual space. The controllable or persuasive spread of discourse loses effectiveness.

\section{The Ideological and Political Education Fails to Achieve Good Effects Because of Unsound Educational Content Structure.}

One of the reasons why the ideological and political education in the new media era cannot achieve good effects is that the current content structure of it is unsound and fails to keep up with the times. It causes the negative factors. In the new media era, the diversified and complicated information, the shared and open resources interweave with each other, urgently requiring the optimization of content structure in ideological and political education. 


\section{The Ideological and Political Education Fails to Exert Overall Effect Because of the Deficiency of Current Carriers.}

The ideological and political education must have carriers to take effect. With the development and application of new media, the traditional carrier form of ideological and political education is backward and inefficient and causes negative factors. On one hand, the information shown by new media has multiple channels and wide coverage, so it makes educator and educatee on the same "information platform" in classroom education, largely reducing the authority and influence of educators. On the other hand, because the carriers brought by new media are diversified, it is outdated to take classroom education as the main carrier. Obviously, the reason why the ideological and political education fails to take effect is that the current carriers are inefficient.

\section{SPECIFIC WAYS FOR THE INNOVATION OF TEACHING METHODS OF IDEOLOGICAL AND POLITICAL COURSE IN THE NEW MEDIA ERA}

\section{A. Make Innovation in Teaching Methods and Means}

College students have active thinking and diversified requirements. The traditional "duck-stuffing" type of teaching cannot attract students' attention and interests. Therefore, it is necessary to reform the teaching methods of ideological and political theory course, changing the stuffing, closed and passive teaching into guided, open and active one. Teachers can change the teaching concept and use interactive teaching, case teaching, topic teaching, and heuristic teaching and teaching through network platform in the classroom.

Classroom teaching solves deep ideological problems of students. It is necessary to correctly guide college students with systematic theoretical course, use scientific theory to arm people and profound principle to persuade, helping students to correctly use Marxist theory to solve problems in life. College students have active thinking and diversified requirements. The traditional "duck-stuffing" type of teaching cannot attract students' attention and interests. Therefore, it is necessary to reform the teaching methods of ideological and political theory course, changing the stuffing, closed and passive teaching into guided, open and active one. Educators should teach according to characteristics of students' physiological and mental development and actual demand in different periods, to better arouse their learning interests. Diversified forms are necessary. Teaching activities like lecture, recitation, debate competition, group discussion and writing papers can motivate students to learn knowledge with interest and active thinking. Furthermore, the carriers of ideological and political education include ideological and political theory course and specialized course. For example, educators can strengthen the education of team spirit, striving spirit, scientific spirit and humanistic spirit as well as innovative thinking.

\section{B. Make Innovation in the Contents of Ideological and Political Education}

It is important to innovate in the contents of ideological and political education. In the new period, the ideological and political education of students should be modern, scientific and systematic. Teachers should correctly guide students with exemplary deeds and the characteristics of times. They can build innovative and open environment and innovate in teaching contents to influence and stimulate students. When innovating in the contents, teachers should: (1)make it close to life. At present, the ideological and political education in our country is backward. In order to effectively solve this problem, teachers should research the social reality to formulate the contents of ideological and political education, so that students can pay more attention to the society and treat social problems with ideological and political knowledge. (2)Improve idea of students. Influenced by the traditional teaching ideas, many students attach little importance to ideological and political education. They think it only supports other disciplines and has little influence on academic records. Therefore, they will learn ideological and political knowledge casually. To solve this problem, when determining the contents of ideological and political education, teachers should put the importance of it in the first chapter to attract students' attention. Students will learn it with correct attitude.

\section{Standardize the Practical Teaching and Enrich the Forms of $I t$}

Form contents and forms of practical teaching according to feature of the course, guide students to participate in classroom practice, social practice and practical activity of scientific research like production practice, social survey, voluntary service, visiting and inspection as well as red tourism, and depend on the network to carry out virtual practice to improve the efficiency of classroom teaching.

Firstly, improve ideological understanding and innovate in the idea of practical teaching. It is a new task faced by colleges in the new situation to promote the practical teaching reform of ideological and political theory course. It is a complicated systematic project with continuous innovation and development. Therefore, we must improve ideological understanding and pay high attention to the practical teaching reform of ideological and political theory course. It is different from students' social practice and daily activities. It is an important part and teaching form of ideological and political theory course focusing on practical activities. It is necessary to strictly standardize the practical teaching links and establish the idea that the practical teaching and the classroom teaching are equally important.

Secondly, increase input to guarantee the fund of practical teaching. In order to guarantee the sustainable development of practical teaching, colleges should set up special fund and bring it in financial budget and ensure it is used reasonably. Meanwhile, strive for the support and help of social resources and strengthen the connection with all walks of life in society. Colleges can depend on enterprises and take advantage of scientific research and talents and follow the cooperative, sharing and win-win principle to establish stable and lasting practical teaching base.

Thirdly, strengthen teaching staff construction and improve practical teaching ability. The teaching reform in colleges cannot do without team construction. It is the same with 
practical teaching of ideological and political theory course. As organizer and pusher of practical teaching, teachers of ideological and political theory course bear important responsibility and play a vital role in it. Therefore, they must have high ideological and political quality, solid theoretical level and strong ability of practical activities. In order to promote the practical teaching reform, colleges should strengthen the teaching staff construction and training, encourage teachers to participate in more social activities to improve quality and better improve practical teaching reform of ideological and political theory course and teaching quality.

\section{Exert the Function of Campus Network}

In the new media era, campus network should become the main and has become the most convenient and fastest channel to achieve ideological and political education.

Instead of only sending some notices and academic records, the campus network should be a platform integrating knowledge, interestingness, thought and care. It is an ideological education platform with strong service function, wide coverage and large amount of information. Students can get information required in their life and learning. Meanwhile, it can enrich the spiritual and cultural life of them.

Timely update and supplement information resources to attract students' attention. In the new media era, the information becomes diversified. In order to arouse students' interest, it is necessary to build and supplement network course library including teaching software database and material library on campus network. At the same time, it should be student-oriented and provide conditions for online exchange of students' learning and life, psychological consulting and occupational guidance. The campus network can be used to carry out colorful activities like academic exchange, science and technology communication and recreational activities and discussion of art. It aims at providing a convenient platform for learning and interaction of teachers and students, making the relationship between teachers and students become closer and helping teachers to efficiently find and solve students' problems in life and learning. Colleges and teachers arouse students' enthusiasm in participating in the construction of campus network. They can use network resources to achieve the ideological and political education for students. At the meantime, students can use their wisdom to promote the development of campus network to a high grade.

\section{CONCLUSION}

In the new media era, opportunities and challenges coexist. Educators of ideological and political education should research with persistence according to new situation and problems and apply research results to guide practice, so that they can accomplish the mission and better improve the pertinence and effectiveness of teaching ideological and political course.

\section{REFERENCES}

[1] Zhang Qin. Innovative Exploration on Working Mechanism of Ideological and Political Education for College Students in the New Media Era [J], Ideological and Theoretical Education, Dec.2014

[2] Yang Jian. Key Points for Methods and Innovation of Ideological and Political Education in Colleges [J], Heilongjiang Science, Jul.2014

[3] Ji Haiju. Research on Ideological and Political Education in Colleges in the New Media Era [M], Nanjing Normal University, Mar.2013

[4] Wang Xianqing. Discussion on Characteristics and Ways for Teaching Method Innovation of Ideological and Political Theory Course in Colleges [J], Journal of Ideological Theoretical Education, 2011(1) 